\title{
Regulation of amino acid transporters in the mammary gland from late pregnancy to peak lactation in the sow
}

\author{
Fang Chen ${ }^{1,2}$, Shihai Zhang ${ }^{1,2}$, Zixiao Deng ${ }^{1}$, Qiqi Zhou', Lin Cheng ${ }^{1}$, Sung Woo Kim³ ${ }^{3}$ Jun Chen ${ }^{1}$
} and Wutai Guan ${ }^{1,2^{*}}$

\begin{abstract}
Background: Milk protein is crucial for milk quality in sows and health of newborn piglets. Plasma amino acids (AA) in sows are important precursors for milk protein synthesis in the mammary gland. In order to study the regulation of AA transported in sow mammary glands and possible underlying mechanisms, we measured the expression of genes coding for milk proteins, AA transporter expressions, and plasma AA concentrations in sows at three different physiological stages (D-17, D1 and D17 of lactation), and then further investigated the regulation of AA transport across the cell membrane by adaptive mechanisms using pig mammary epithelial cells (PMEC) as an in vitro model. PMEC were cultured in DMEM:F12 with 4 amino acid concentrations $(0 \times A A$ complex, $1 \times$ AA complex, $5 \times A A$ complex, and $25 \times$ AA complex). Classes of AA complexes evaluated in this study included neutral AAs (L-Ala + L-Ser + L-Cys), acidic AAs (L-Asp, L-Glu) and neutral + basic AAs (L-Ala + L-Ser + L-Cys + L-Lys).
\end{abstract}

Results: Our results indicated that mRNA expression of genes coding for milk protein (as1-casein, as2-casein, $\beta$-casein and k-casein) increased significantly with the advance of physiological stage $(P<0.05)$, and plasma concentrations of most AAs including threonine, serine, glutamate, alanine, valine, cysteine, methionine, isoleucine and tyrosine were greater at D1 of lactation compared with D-17 and D17 of lactation $(P<0.05)$. Additionally, protein and gene expressions of AA transporters including excitatory AA transporter 3 (EAAT3), alanine/serine/cysteine/threonine transporter (ASCT1) and sodium-coupled neutral AA transporter 1 (SNAT2) were greater in lactating sow mammary glands compared with sow mammary glands in late pregnancy $(P<0.05)$. The mRNA expressions of SLC38A2, SLC1A1, SLC6A14 increased significantly in the cell mediums supplemented with $5 \times$ and $25 \times$ of AA complexes compared with those cells cultured in DMEM/F12 cell medium $(P<0.05)$. The mRNA expressions of SLC38A, SLC1A4, and SLC6A14 also increased in EBSS cell medium compared to DMEM/F12. However, only mRNA expression of SLC38A decreased when AA complex was added into EBSS $(P<0.05)$.

Conclusion: AA transportation was positively regulated in sow mammary glands with the advance of physiological stage from late pregnancy to peak of lactation and AA transporters in PMECs were adaptively regulated by changed AA concentrations.

Keywords: Amino acid transporter, Lactation, Mammary epithelial cell, Milk protein, Sow

\footnotetext{
*Correspondence: wtguan@scau.edu.cn

'Department of Animal Science, South China Agricultural University,

Guangzhou 510642, China

${ }^{2}$ National Engineering Research Center for Breeding Swine Industry,

Guangzhou 510642, China

Full list of author information is available at the end of the article
} 


\section{Background}

The mammary gland undergoes extensive morphological, structural, and functional changes from pregnancy to lactation in order to provide optimal nutritional support for offspring with different nutrient requirements at different developmental stages [1-4]. Studies in several species indicated that there may be species-specific changes in milk composition in addition to the changes in amount of milk secretion at different stages of lactation, corresponding to growth phases of the young offspring [5]. Research in dairy cows and mice discussed possible mechanisms of this phenomenon, and reported that there was a rapid adaptation in mammary glands at different stages of development with altered expression of several genes involved in lactogenesis $[6,7]$. However, there are limited reports in the peer reviewed literature focusing on regulation of milk protein synthesis in the sow, a multifetal mammal with high daily milk production.

Our lab previously screened 1,524 genes differentially expressed at three different physiological stages (D-17, D1, D17 of lactation) using Affymetrix Porcine GeneChip and Gene Ontology analysis. Results indicated that most of the regulated genes were involved in transportation of nutrients and biosynthetic processes related to nutrients synthesis in mammary tissue [8]. Considering that protein, fatty acids, and lactose are the major components in sow milk and essential for growth and health of neonatal pigs, we further investigated regulatory mechanisms of fatty acid and lactose synthesis in mammary tissue in two previous published papers $[9,10]$. Milk proteins are of importance during the entirety of lactation to support growth and health of nursing piglets and the changes in milk protein contents at different stages of lactation are more pronounced compared to fatty acids and lactose [11]. Therefore, understanding mechanisms of milk protein synthesis and their regulation in pig mammary glands is important for development of technology to enhance growth and health of nursing piglets.

The mammary gland has a large demand for AAs to meet the requirements for milk protein synthesis during lactation and the availability of these AAs to the mammary system is critical for optimizing milk production [12]. It is well documented that intracellular availability of AAs is controlled by coordinated activity of AA transport systems and their respective carrier proteins, which are located on the cellular membrane and are responsible for channeling AAs from the arterial blood across the cell membrane $[13,14]$. However, the regulation mechanism of transporter systems in sow mammary glands at different physiological stages of mammary glands with changed milk protein content are unknown.

Therefore, the objectives of this study were to 1) investigate the regulation of amino acid transporters in sow mammary glands at 3 different physiological stages (D-
17 , D1, and D17 of lactation), and 2) evaluate regulatory mechanisms of AA transporters under conditions with varied concentrations of AAs using PMECs as an in vitro model.

\section{Methods}

Animal management and tissue sample collection

Six multiparous (four to six parities) Large White sows on D90 of pregnancy were selected randomly from the Huizhou Swine Breeding Center and were fed and managed by established procedures. Sows were housed in individual feeding stalls with free access to water and feed. The diets were mainly based on corn and soybean meal containing nutrients meeting or exceeding NRC (2012) requirements (Table 1 ).

Mammary glands were categorized by their anatomical locations according to the standard described by Kim et al. [15]. Approximately $1 \mathrm{~g}$ of mammary tissue was excised using the surgical method reported by Manjarin et al. [16]. Briefly, sows were anesthetized by intramuscular injection of mixed anesthetics that contained $500 \mathrm{mg}$ Shutai (Chongbiwei Biological Technology Inc., Beijing, China) and $350 \mathrm{mg}$ ketamine (Agricultural Bureau of

\section{Table 1 Ingredients of the sow diets (air-dry basis)}

\begin{tabular}{lll}
\hline Ingredients, \% & Late stage of pregnancy & Lactation period \\
\hline Corn & 65.60 & 62.30 \\
Soybean meal & 22.0 & 23.0 \\
Soybean oil & 1.00 & 3.00 \\
Wheat bran & 8.0 & 5.0 \\
Fish meal & 0.0 & 3.0 \\
Limestone & 0.9 & 1.0 \\
Calcium phosphate & 1.2 & 1.3 \\
Salt & 0.3 & 0.4 \\
Vitamin premix & 0.5 & 0.5 \\
Mineral premix & 0.5 & 0.5 \\
Total & 100.0 & 100.0 \\
Nutrition standards, \% & & \\
DE, MJ/kg & 13.45 & 13.87 \\
CP & 16.05 & 17.71 \\
CF & 3.75 & 3.40 \\
EE & 4.12 & 5.76 \\
Ca & 0.86 & 0.84 \\
P & 0.63 & 0.68 \\
AP & 0.41 & 0.44 \\
Lys & 0.86 & 1.02 \\
\hline
\end{tabular}

aprovided the following per kilogram of diet: 2,400 IU of vitamin A, 3,000 IU of vitamin $D_{3}, 60 \mathrm{mg}$ of vitamin $E, 5 \mathrm{mg}$ of vitamin $\mathrm{K}, 5 \mathrm{mg}$ of vitamin $B_{1}$, $12.5 \mathrm{mg}$ of vitamin $B_{2}, 24 \mathrm{mg}$ of pantothenic acid, $50 \mathrm{mg}$ of niacin, $5 \mathrm{mg}$ of vitamin $B_{6}, 0.037 \mathrm{mg}$ of vitamin $B_{12}, 2.2 \mathrm{mg}$ of folacin, $0.1 \mathrm{mg}$ of biotin bProvided the following per kilogram of diet: $8 \mathrm{mg}$ of $\mathrm{Cu}, 60 \mathrm{mg}$ of $\mathrm{Fe}, 35 \mathrm{mg}$ of $\mathrm{Mn}, 65 \mathrm{mg}$ of $\mathrm{Zn}, 0.35 \mathrm{mg}$ of $\mathrm{I}, 0.3 \mathrm{mg}$ of Se 
Guangzhou City supply, Guangzhou, China) dissolved in $0.9 \%$ sodium chloride. After disinfecting the mammary glands with $75 \%$ ethanol, a 2 -cm incision was made vertical to the plica lateralis, aligned with the nipple, and approximately $5 \mathrm{~cm}$ dorsal to the perimeter of the nipple areola. About $0.8 \mathrm{~g}$ mammary tissue was excised with a scalpel in a circular motion. The incision was closed with simple interrupted sutures using braided silk (Jinhuan, Inc., Shanghai, China). Sows received an intramuscular injection of ampicillin sodium (Jiacheng Technology, Inc., Zhuhai, China) at a dose of $10 \mathrm{mg} / \mathrm{kg}$ immediately after biopsy and then 24 and $48 \mathrm{~h}$ later. Sutures were removed $7 \mathrm{~d}$ after biopsy. Tissue samples were immediately frozen in liquid nitrogen. In total, 18 mammary gland samples were collected. All procedures were conducted following the protocols approved by the Committee for the Care and Use of Experimental Animals at South China Agricultural University.

\section{Milk collection and milk composition analysis}

Colostrum samples were collected on the day of parturition, within $4 \mathrm{~h}$ of the birth of the first piglet. Milk samples were collected on D17 post-farrowing following the intramuscular administration of $2 \mathrm{~mL}$ oxytocin (10 IU/mL; NVS, Basel, $\mathrm{CH}$ ) before percutaneous biopsies. The samples were stored without preservative at $-70{ }^{\circ} \mathrm{C}$ until analyzed for milk composition. An automatic milk composition analyzer (ML4AC, Beijing, China) was used to measure the contents of lactose, protein, fat and solidsnot-fat components in the milk.

\section{Cell culture to evaluate effect of AA concentrations on gene expression of AA transporters in PMEC}

PMEC cells used in this study were previously separated and characterized from mammary glands of lactating sows in our lab. Briefly, a $1-\mathrm{cm}^{3}$ sample of mammary tissue from a lactating sow was cut using surgical scissors and then the tissue pieces were dissociated by gentle agitation at $37{ }^{\circ} \mathrm{C}$ for $12 \mathrm{~h}$. After filtration through stainless steel mesh (80mesh) to remove dissociated tissue and debris, the cells were collected by centrifugation at $800 \times g$ for $3 \mathrm{~min}$ at $25{ }^{\circ} \mathrm{C}$. The isolated PMEC cells were cultured in DMEM/ F12 (GIBCO) containing 10\% fetal calf serum, insulin $(5 \mu \mathrm{g} / \mathrm{mL})$, hydrocortisone $(5 \mu \mathrm{g} / \mathrm{mL})$, ITS $(5 \mu \mathrm{g} / \mathrm{mL})$, IGF$1(10 \mathrm{ng} / \mathrm{mL})$, EGF $(10 \mathrm{ng} / \mathrm{mL}), 50 \mu \mathrm{g} / \mathrm{mL}$ gentamicin and PSN antibiotics. The attached cells were washed 3 times with D-PBS containing PSN antibiotics after a 24-h cultivation, and then cell medium was added for continued culturing. Immunohistochemistry and RT-PCR were further performed to characterize these separated mammary epithelial cells by protein expression of cytokeratin-18 (an intermediate filament specific for epithelial cells), and gene expression of $\beta$-casein (a specific marker for mammary epithelial cells), $\beta$-lactoglobulin and $\alpha$-lactalbumin.
Cells were grown in DMEM:F12 (GIBCO, Thermo Fisher Scientific, Waltham, MA, USA), containing $5 \%(w / v)$ heat-inactivated fetal calf serum (GIBCO, Thermo Fisher Scientific, Waltham, MA, USA), insulin (bovine, $5 \mu \mathrm{g} / \mathrm{mL}$, Sigma, St. Louis, Mo, USA), gentamicin $(50 \mu \mathrm{g} / \mathrm{mL}$, Sigma, St. Louis, MO, USA) and combined antibiotics (penicillin, $100 \mathrm{IU} / \mathrm{mL}$ and streptomycin $0.1 \mathrm{mg} / \mathrm{mL}$, Biological Industries) at $37{ }^{\circ} \mathrm{C}$ under humidified $95 \%$ air $/ 5 \% \mathrm{CO}_{2}$. When the cells were approximately $80 \%$ confluent, they were seeded in 6-well culture plates $\left(5 \times 10^{5}\right.$ cells/well) and then were assigned to 4 concentrations of AA complexes in each of 2 mediums for each of 3 classes of AA complexes. The mammary epithelial cells were allowed to attach overnight in 6-well culture plates and then AA complexes (including $0 \times$ AA complex, $1 \times$ AA complex, $5 \times$ AA complex, and $25 \times$ AA complex) were added into cell medium for $4 \mathrm{~h}$ treatment for subsequent real time-PCR analysis. There were three classes of AA complexes evaluated in this study, which included neutral AAs ( $L$-Ala $+L$-Ser $+L$-Cys), acidic AAs ( $L$-Asp, $L$-Glu) and neutral + basic AAs $(L-\mathrm{Ala}+L$ $\mathrm{Ser}+L$-Cys $+L$-Lys). Individual AAs were purchased from Sigma Company (St. Louis, MO, USA) and the concentrations of AA in $1 \times$ AA complexes were compounded according to their concentrations in the DMEM:F12 cell medium as follows: neutral AAs ( $L$-Ala, $0.05 \mathrm{mmol} / \mathrm{L} / \mathrm{L}^{-}$ Ser $0.25 \mathrm{mmol} / \mathrm{L} ; L$-Cys $0.1 \mathrm{mmol} / \mathrm{L})$, acidic AAs ( $L$-Asp $0.05 \mathrm{mmol} / \mathrm{L} ; L$-Glu, $0.05 \mathrm{mmol} / \mathrm{L})$; neutral + basic AAs $(L-$ Ala, $0.05 \mathrm{mmol} / \mathrm{L} ; L$-Ser $0.25 \mathrm{mmol} / \mathrm{L} ; L$-Cys $0.1 \mathrm{mmol} /$ $\mathrm{L}$; $L$-Lys, $0.499 \mathrm{mmol} / \mathrm{L})$. The AA concentrations in $5 \times \mathrm{AA}$ complexes were compounded as follows: neutral AAs $(L-$ Ala, $0.25 \mathrm{mmol} / \mathrm{L}$; $L$-Ser $1.25 \mathrm{mmol} / \mathrm{L} ; L$-Cys $0.5 \mathrm{mmol} / \mathrm{L})$, acidic AAs ( $L$-Asp $0.25 \mathrm{mmol} / \mathrm{L} ; L$-Glu, $0.25 \mathrm{mmol} / \mathrm{L}$ ); neutral + basic AAs (L-Ala, $0.25 \mathrm{mmol} / \mathrm{L} ; L$-Ser $1.25 \mathrm{mmol} /$ L; $L$-Cys $0.5 \mathrm{mmol} / \mathrm{L} ; L$-Lys, $2.495 \mathrm{mmol} / \mathrm{L}$ ), and the AA concentrations in $25 \times$ AA complexes were compounded as follows: neutral AAs ( $L$-Ala, $1.25 \mathrm{mmol} / \mathrm{L} ; L-S e r 6.25 \mathrm{mmol} /$ L; $L$-Cys $2.5 \mathrm{mmol} / \mathrm{L}$ ), acidic AAs (L-Asp $1.25 \mathrm{mmol} / \mathrm{L}$; $L$-Glu, $1.25 \mathrm{mmol} / \mathrm{L}$ ); neutral + basic AAs (L-Ala, $1.25 \mathrm{mmol} / \mathrm{L} ; L$-Ser $6.25 \mathrm{mmol} / \mathrm{L} ; L$-Cys $2.5 \mathrm{mmol} /$ L; $L$-Lys, $12.475 \mathrm{mmol} / \mathrm{L}$ ). AA depletion was achieved by changing the cell medium to Earle's Balanced Salt solution (EBSS, Sigma, St. Louis, MO, USA) containing insulin, hydrocortisone and prolactin for $4 \mathrm{~h}$ and then AA complexes (including $0 \times$ AA complex, $0.04 \times$ AA complex, $5 \times$ AA complex, and $25 \times$ AA complex) were subsequently added into EBSS. The components of EBSS were as following: $\mathrm{CaCl}_{2} \cdot 2 \mathrm{H}_{2} \mathrm{O}, 0.265 \mathrm{~g} / \mathrm{L}$; $\mathrm{MgSO}_{4}, 0.09767 \mathrm{~g} / \mathrm{L}, \mathrm{KCl}, 0.4 \mathrm{~g} / \mathrm{L} ; \mathrm{NaHCO}_{3}, 8.2 \mathrm{~g} / \mathrm{L}$; $\mathrm{NaCl}, 6.8 \mathrm{~g} / \mathrm{L} ; \mathrm{NaH}_{2} \mathrm{PO}_{4}, 0.122 \mathrm{~g} / \mathrm{L} ; D$-Glucose, $1.0 \mathrm{~g} / \mathrm{L}$; Phenol RedCNa, $0.011 \mathrm{~g} / \mathrm{L}$. The cells were harvested after $4 \mathrm{~h}$ for mRNA determination using Real-time PCR. Gene expressions of SLC38A2 and SLC1A4 were measured in those cells treated with neutral AA complexes, SLC1A1 was measured in those cells treated 
with acidic AA complex, and SLC6A14 was measured in those cells treated with neutral + basic AAs complex.

\section{Measurement of the plasma AAs concentration}

Plasma AA concentrations of sows were determined by automatic AA analyzer (LP-8900, Hitachi, Tokyo, Japan). Plasma samples $(400 \mu \mathrm{L})$ were deproteinized with $1,200 \mu \mathrm{L}$ of $10 \%$ sulfosalicylic acid and the supernatant was assayed for AA composition. S-(2-amino-ethyl)- $L$ cysteine was used as an internal standard.

\section{Real-time PCR}

Total RNA was isolated from $100 \mathrm{mg}$ tissue samples using TRIZOL reagent (Invitrogen, Carlsbad, CA, USA) according to the manufacturer's instructions. The RNA quality was confirmed by calculating the OD 260/280 ratio via a spectrophotometer, and the integrity of the RNA was verified by agarose gel electrophoresis. The qPCR was performed in an ABI Prism 7500 Sequence Detection System using SYBR Green Real-time PCR Master Mix (Toyobo, Osaka, Japan) in a final volume of $20 \mu \mathrm{L}$ after cDNA synthesis which was performed using a PrimeScript RT reagent kit with gDNA eraser (Takara, Dalian, China) according to the protocol described by Shu et al. [8]. All the primer sequences for PCR are shown in Table 2 and Table 3 . The thermal cycling conditions of qPCR reactions were as follows: $95^{\circ} \mathrm{C}$ for $1 \mathrm{~min}$ followed by 40 cycles of denaturation at $95{ }^{\circ} \mathrm{C}$ for $15 \mathrm{~s}$, annealing at $59{ }^{\circ} \mathrm{C}$ for $15 \mathrm{~s}$, and extension at $72{ }^{\circ} \mathrm{C}$ for $40 \mathrm{~s}$. A melting curve analysis was also performed for each gene to confirm the production of a single specific amplification product. The amplification efficiency of each gene was counted and the relative expression level for each gene was calculated using the equation described previously [17]: $R_{0},{ }_{T} / R_{0}, R=(1+$ $\left.\mathrm{E}_{\mathrm{R}}\right)^{\mathrm{Ct}, \mathrm{R}} /\left(1+\mathrm{E}_{\mathrm{T}}\right)^{\mathrm{Ct}, \mathrm{T}}(\mathrm{E}=$ amplification efficiency, $\mathrm{R}=$ reference gene, $T=$ target gene, $E_{R}=$ amplification efficiency of reference gene, $\mathrm{E}_{\mathrm{T}}=$ amplification efficiency of target gene, $\mathrm{C}_{\mathrm{t}, \mathrm{R}}=$ threshold cycles for reference gene, $\mathrm{C}_{\mathrm{t}, \mathrm{T}}=$ threshold cycles for target gene).

Table 2 Primers for the genes of milk protein

\begin{tabular}{llll}
\hline $\begin{array}{l}\text { Gene } \\
\text { name }\end{array}$ & Accession number & Primers $\left(5^{\prime} \rightarrow 3^{\prime}\right)$ & Size, bp \\
\hline CSN1S1 & NM_001004029 & F: ACAAATGAGGACAAGCATACCC & 175 \\
& & R: GAGGGATGTTGGTGAATAATGG & \\
CSN1S2 & NM_001004030 & F: GAAGTGGGATATGCCAGCAG & 148 \\
& & R: CCTGGAGATATTGGGGAAC & \\
CSN2 & NM_214434 & F: TCATCCTTGCCTGCTTCGT & 367 \\
& & R: GGCATTCCTTTACGCTTGG & \\
CSN3 & NM_001004026 & F: GCCTATCCTGGCATTAACACTG & 286 \\
& & R: TGGGTAGACATTGGCTGGTC & \\
\hline
\end{tabular}

Abbreviation: CSN1S1 aS1-casein, CSN1S2 aS2-casein, CSN2 $\beta$-casein, CSN3 k-casein

\section{Western blot}

Mammary tissue samples were homogenized in RIPA lysis buffer (Beyotime, Nanjing, China). Extracted protein samples were heated in water at $100{ }^{\circ} \mathrm{C}$ for $5 \mathrm{~min}$ and separated by electrophoresis (Bio-Rad, Richmond, CA) in 12\% SDS-PAGE gel before being electroblotted (Bio-Rad) onto a polyvinylidene fluoride membrane (Millipore, Billerica, MA). After polyvinylidene fluoride membranes were blotted with Tris buffer containing 5\% fat-free dry milk and 0.05\% Tween-20 (TBST; 0.05\% Tween 20, $100 \mathrm{mmol} / \mathrm{L}$ of Tris- $\mathrm{HCl}$, and $150 \mathrm{mmol} / \mathrm{L}$ of $\mathrm{NaCl}, \mathrm{pH} 7.5$ ) for $1 \mathrm{~h}$ at $25{ }^{\circ} \mathrm{C}$, they were rinsed in TBST 4 times and incubated overnight at $4{ }^{\circ} \mathrm{C}$ with primary antibodies: EAAT3 (Sigma Aldriche, sc-25658), ASCT1(Sigma Aldriche, sc-50801), and SNAT2 (Sigma Aldriche, sc-166366) with ratios of $1: 1,000,1: 800$, and 1:1,000 respectively. Rabbit IgG (5 $\mu \mathrm{g} /$ $\mathrm{mL}$; Sigma) was used as the primary antibody for controls. After washing, membranes were incubated with secondary antibody (Amersham Biosciences). The chemiluminescent signal was detected by using ECL reagents (Beyotime, Nanjing, China), and bands were quantified by Image Processing Software (Image Pro Plus6.0).

\section{Statistical analysis}

Milk, plasma amino acid, and mRNA expression data were analyzed by one-way analysis of variance (ANOVA) using SPSS 17.0 with physiological stage as the fixed effect in the model and variation among sows within physiological stage as the random error. Cell culture data were also analyzed as a one-way classification with AA concentration/medium combination (treatment) as a fixed effect and variation among replicates within treatment as random error. The cell culture experiment was performed with six replicates per treatment combination. Data are shown as means \pm SEM. $P<0.05$ was considered to be statistically significant and $P<0.01$ was considered to be highly statistically significant.

\section{Results}

Component analysis of colostrum and milk

It is clear that there were significant differences in lactose, milk fat and milk protein between colostrum and milk (Table 4). The concentrations of lactose and milk fat were greater in milk compared to colostrum $(P<0.05)$, while milk protein concentration was less in milk at D17 of lactation $(P<0.05)$. There was little evidence of a difference in solids-not-fat $(P>0.1)$.

\section{The mRNA expression of milk proteins (as1-casein, as2- casein, $\beta$-casein and $\mathrm{k}$-casein) in mammary tissue at different physiological stages}

The gene expressions of these four important milk proteins increased markedly with physiological stage with the least 
Table 3 Primers for the genes of AA transporters

\begin{tabular}{|c|c|c|c|}
\hline Gene name & Gene accession & Primers sequence $\left(5^{\prime} \rightarrow 3^{\prime}\right)$ & Size, bp \\
\hline \multirow[t]{2}{*}{$\overline{S L C I A 1}$} & NM_001164649 & F: TCCACTCCATTGTTATTCTGCC & 172 \\
\hline & & R: TTGTCCACCTGGTTCTTCTCTTC & \\
\hline \multirow[t]{2}{*}{ SLCIA2 } & HSU03505 & F: AGCAGGTGGAAGTGCGAATG & 160 \\
\hline & & R: CGAAGAAGCCCTCCACACACT & \\
\hline \multirow[t]{2}{*}{ SLCIA3 } & BC037310 & F: TCACGCAGTCATCGTCTTGC & 171 \\
\hline & & R: TTGTCCACGCCATTGTTCTC & \\
\hline \multirow[t]{2}{*}{ SLCIA4 } & XM_003125088 & F: AGACCTCTCTITGATCCTGGC & 190 \\
\hline & & R: TGTTTCCTCCTCTGATTTGCA & \\
\hline \multirow[t]{2}{*}{ SLCIAS } & XM_003127237 & F: AAGGAGTCGGTTCTGTGATGG & 108 \\
\hline & & R: TAAAAGTCGGCGAGGGTGA & \\
\hline \multirow[t]{2}{*}{ SLCBA1 } & EU587017 & F: TGCATGACATTGTCCGCAG & 140 \\
\hline & & R: TTGGATAAAAGGCAACCCG & \\
\hline \multirow[t]{2}{*}{$S L C 3 A 2$} & XM_003353809 & F: TGAACAGCAGCGTGACTGTG & 162 \\
\hline & & R: ACTGGCGGATGTAGGAGAAGA & \\
\hline \multirow[t]{2}{*}{ SLC6A14 } & GQ387269 & F: TCCAGAAGCTCTAGCCCAACT & 190 \\
\hline & & R: CAAAACCAAGCAGCAACCC & \\
\hline \multirow[t]{2}{*}{ SLC6A15 } & NM_018057 & F: GCTTCTTGGGCTITGTGATG & 232 \\
\hline & & R: GGTGAGTCCGTGCTTGTTTC & \\
\hline \multirow[t]{2}{*}{ SLC7A1 } & NM_001012613 & F: GCCTGAGAGCAAGACCAAAC & 166 \\
\hline & & R: GCCGTAGCCGAAGTAGATGA & \\
\hline \multirow[t]{2}{*}{ SLCTA2 } & EU155140 & F: GCCCCAGAATCAGCAAAAAGTA & 97 \\
\hline & & F: GATGCTGAAGGCTGGCAAAA & \\
\hline \multirow[t]{2}{*}{ SLC7A5 } & NM_003486 & F: CTCTTCCTGATCGCCGTCTC & 165 \\
\hline & & R: CTTCTGACACAGGACGGTCGT & \\
\hline \multirow[t]{2}{*}{ SLC7A6 } & NM_003983 & F: CTGCCGCCTGCATGTGT & 78 \\
\hline & & R: TGTGCCCCACTTGACATAGG & \\
\hline \multirow[t]{2}{*}{ SLCTA7 } & EU047705 & F: TTTGGTTCCCAAGGTTGCA & 95 \\
\hline & & R: GCAGCTTCCTGGCATTGC & \\
\hline \multirow[t]{2}{*}{ SLCTAB } & AF135830 & F: TCGCTGTGACTTITGGAGAGA & 112 \\
\hline & & R: CGGGAGGAGGTGAAGAGG & \\
\hline \multirow[t]{2}{*}{ SLC7A10 } & XM_003127014 & F: TGGACCCTCGAAAGAACCTAC & 216 \\
\hline & & R: TGATCCCTCCGAAAGTGGA & \\
\hline \multirow[t]{2}{*}{ SLC7A11 } & AB271957 & F: AATGTGGCCTACTTCACGACC & 193 \\
\hline & & R: CCTCCCGAGATGCAACATAGA & \\
\hline \multirow[t]{2}{*}{ SLC38A1 } & XM_003355629 & F: AAGAACCTGGGCTATCTCGG & 138 \\
\hline & & R: TGTTGCGTTAGGACTCGTTG & \\
\hline \multirow[t]{2}{*}{ SLC38A2 } & NM_018976 & F: GTTACCTTTGGTGATCCAGGC & 96 \\
\hline & & R: ACCAATGACACCAGCAGAACC & \\
\hline \multirow[t]{2}{*}{ SLC38A4 } & XM_003355630 & F:GTTCTITGCCTTCACTCACTA & 186 \\
\hline & & R: GACCCAAGCCTCCAGATT & \\
\hline \multirow[t]{2}{*}{ MRPL39 } & AY610067 & F: CAAAAGAGAACCTACATTCCTTCACA & 100 \\
\hline & & R: TCTAATGCCACTITTGCTTCAACT & \\
\hline
\end{tabular}


Table 4 The component analysis of colostrum and milk

\begin{tabular}{llll}
\hline Item, \% & Colostrum & Milk & $P$-value \\
\hline Lactose & $9.38 \pm 0.19^{\mathrm{A}}$ & $11.29 \pm 0.37^{\mathrm{B}}$ & 0.00 \\
Milk fat & $2.61 \pm 0.32^{\mathrm{B}}$ & $9.45 \pm 1.59^{\mathrm{A}}$ & 0.00 \\
Milk protein & $8.06 \pm 0.23^{\mathrm{A}}$ & $3.55 \pm 0.39^{\mathrm{B}}$ & 0.00 \\
Solids-not-fat & $19.32 \pm 0.56$ & $17.86 \pm 1.04$ & 0.27 \\
\hline
\end{tabular}

Note: All data shown as means \pm SEM, values with different capital letter superscripts differ $(P<0.01)$

expression at D-17, intermediate expression at D1 and the greatest expression at D17 of lactation $(P<0.05)$ (Table 5$)$.

\section{Concentration of AAs in sow plasma at different physiological stages}

The concentrations of AAs in sow plasma differed among the three different physiological stages (including D-17, D1 and D17 of lactation) (Table 6. Several AA concentrations including threonine, serine, glutamate, alanine, valine, cysteine, methionine, isoleucine, tyrosine, lysine and histidine were significantly higher on the first day of lactation than D-17 and D17 of lactation $(P<0.05)$. In addition, the concentration of phenylalanine was significantly higher during lactation compared with pregnancy $(P<0.05)$, and the concentrations of aspartic acid and glutamate were greater on D1 compared to D-17 $(P<0.05)$. There was little evidence of differences in leucine, ornithine and arginine at different physiological stages.

\section{The mRNA expressions of AA transporters at different stages (D-17, D1 and D17) in sow mammary glands} We estimated the gene expressions of 19 AA transporters (including anionic, cationic, neutral, neutral cationic and heavy subunit AA transporters) related to milk protein synthesis at 3 physiological stages (D-17, D1 and D17 of lactation) in this study.

The gene $S L C 1 A 1$ had the greatest expression among 4 anionic AA transporters (including SLC1A1, SLC1A2, $S L C 1 A 3$ and $S L C 7 A 11$ ), and its expression increased significantly at D1, at which day the sows transited from pregnancy to lactation, and then decreased at D17 of lactation (Fig. $1, P<0.05$ ). We estimated gene expressions of 4 cationic AA transporters (SLC7A1, SLC7A2, SLC7A6, $S L C 7 A 7)$ (Fig. 2). Expression of SLC7A2 decreased at D17

Table 5 The relative mRNA abundance of CSN1S1, CSN2, CSN1S2 and CSN3

\begin{tabular}{lllll}
\hline Gene & D-17 & D1 & D17 & $P$-value \\
\hline CSN1S1 & $69.56 \pm 10.55^{\mathrm{A}}$ & $497.22 \pm 24.23^{\mathrm{B}}$ & $1179.49 \pm 74.96^{\mathrm{C}}$ & 0.00 \\
CSN1S2 & $7.45 \pm 1.46^{\mathrm{A}}$ & $224.86 \pm 52.09^{\mathrm{B}}$ & $1673.83 \pm 190.20^{\mathrm{C}}$ & 0.00 \\
CSN2 & $1.10 \pm 0.17^{\mathrm{A}}$ & $69.31 \pm 11.44^{\mathrm{B}}$ & $170.75 \pm 19.44^{\mathrm{C}}$ & 0.00 \\
CSN3 & $12.73 \pm 1.55^{\mathrm{A}}$ & $394.18 \pm 49.17^{\mathrm{B}}$ & $1193.37 \pm 132.85^{\mathrm{C}}$ & 0.00
\end{tabular}

Note: All data shown as means \pm SEM, values with different capital letter superscripts differ $(P<0.01)$
Table 6 Comparison of free AA in sow blood plasma at different physiological stages

\begin{tabular}{|c|c|c|c|c|}
\hline$\overline{\mathrm{AA}}, \mu \mathrm{mol} / \mathrm{L}$ & $D-17$ & D 1 & D 17 & $P$-value \\
\hline Thr & $21.03 \pm 2.00^{\mathrm{A}}$ & $47.44 \pm 4.31^{B}$ & $15.26 \pm 1.28^{\mathrm{A}}$ & 0.00 \\
\hline Ser & $15.99 \pm 1.73^{\mathrm{a}}$ & $22.27 \pm 2.14^{b}$ & $14.42 \pm 1.09^{\mathrm{a}}$ & 0.02 \\
\hline Glu & $22.35 \pm 0.65^{a}$ & $27.19 \pm 3.33^{b}$ & $23.15 \pm 1.56^{\mathrm{ab}}$ & 0.03 \\
\hline Gly & $70.11 \pm 3.48^{B}$ & $47.34 \pm 1.49^{\mathrm{Aa}}$ & $56.40 \pm 1.26^{\mathrm{Ab}}$ & 0.00 \\
\hline Ala & $34.30 \pm 3.00^{\mathrm{A}}$ & $56.75 \pm 5.44^{B}$ & $25.91 \pm 0.86^{A}$ & 0.00 \\
\hline Val & $1.77 \pm 0.11^{\mathrm{A}}$ & $5.14 \pm 0.68^{B}$ & $2.63 \pm 0.26^{A}$ & 0.00 \\
\hline Cys & $13.26 \pm 0.99^{A}$ & $18.71 \pm 1.60^{B}$ & $11.20 \pm 0.67^{A}$ & 0.00 \\
\hline Met & $27.15 \pm 1.22^{\mathrm{A}}$ & $37.87 \pm 3.98^{B}$ & $26.54 \pm 0.85^{A}$ & 0.01 \\
\hline lle & $20.14 \pm 1.33^{\mathrm{A}}$ & $30.82 \pm 3.73^{B}$ & $21.32 \pm 0.81^{A}$ & 0.01 \\
\hline Leu & $18.33 \pm 0.44$ & $22.46 \pm 2.68$ & $17.92 \pm 1.85$ & 0.24 \\
\hline Tyr & $22.08 \pm 1.49^{\mathrm{Aa}}$ & $32.05 \pm 2.95^{B}$ & $28.18 \pm 0.92^{\mathrm{Ab}}$ & 0.01 \\
\hline Phe & $12.74 \pm 1.03^{\mathrm{Aa}}$ & $18.25 \pm 2.36^{\mathrm{Ab}}$ & $20.01 \pm 1.09^{B}$ & 0.03 \\
\hline Orn & $6.43 \pm 0.69$ & $8.59 \pm 1.46$ & $6.68 \pm 0.61$ & 0.27 \\
\hline Lys & $18.86 \pm 2.08^{\mathrm{A}}$ & $34.41 \pm 2.77^{B}$ & $20.31 \pm 2.17^{A}$ & 0.00 \\
\hline His & $8.75 \pm 1.09^{\mathrm{a}}$ & $13.16 \pm 1.62^{b}$ & $10.36 \pm 1.49^{a}$ & 0.02 \\
\hline Arg & $42.28 \pm 3.61$ & $40.86 \pm 3.61$ & $42.01 \pm 5.85$ & 0.31 \\
\hline Asp & $1.03 \pm 0.17^{a}$ & $1.96 \pm 0.21^{b}$ & $1.44 \pm 0.15^{\mathrm{ab}}$ & 0.04 \\
\hline
\end{tabular}

Note: All data shown as means \pm SEM, values with the same lower case letter superscripts do not differ $(P>0.05)$, with different lower case letter superscripts differ $(P<0.05)$, and with different capital letter superscripts differ $(P<0.01)$

postpartum compared with D-17 and D1 $(P<0.05)$, while SLC7A6 significantly increased along with the physiological stage $(P<0.05)$. Gene expressions of 8 neutral AA transporters were estimated, including SLC1A4, SLC1A5, SLC7A5, SLC7A10, SLC38A4, SLC7A8, SLC38A1, and SLC38A2 (Fig. 3). Expressions of SLC1A4, SLC1A5 and

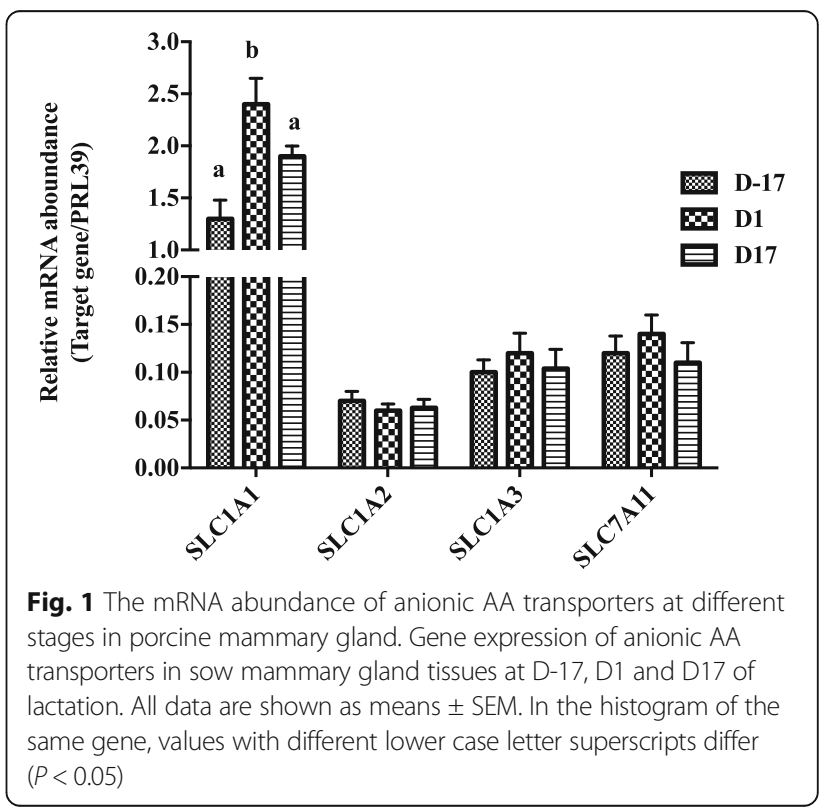




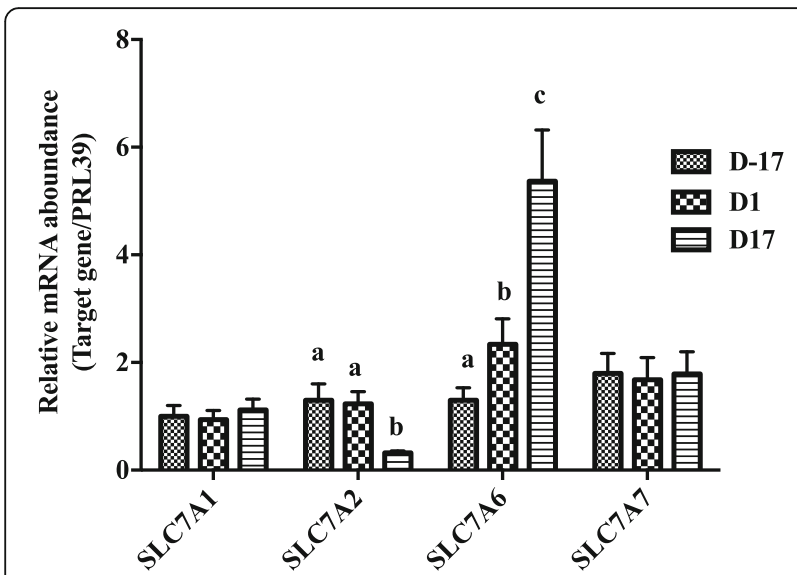

Fig. 2 The mRNA abundance of cationic AA transporters at different stages in porcine mammary gland. Gene expression of cationic AA transporters in sow mammary gland tissues at D-17, D1 and D17 of lactation. All data are shown as means \pm SEM. In the histogram of the same gene, values with different lower case letter superscripts differ $(P<0.05)$

SLC38A2 increased with time of sample $(P<0.05)$, while the expressions of SLC7A10 and SLC38A1 decreased at D17 of lactation compared with D-17 $(P<0.05)$, and expression of SLC7A8 was greatest on D1 compared to D-17 and D17 $(P<0.05)$. Gene expressions of neutral cationic AA transporters and heavy subunit AA transporters (SLC6A14, SLC3A1, SLC3A2) at three different physiological stages are shown in Fig. 4. Expression of SLC6A14 increased over 70 fold on D1 postpartum compared to pregnancy $(P<0.05)$, and then continued to increase at a lesser rate to D17 of lactation $(P<0.05)$.
There was little evidence of differences in $S L C 3 A 2$ at the 3 different physiological stages, but SLC3A1 increased at D17 of lactation, compared with the other two time points $(P<0.05)$.

Protein expression of ASCT1 (SLC1A4), EAAT3 (SLC1A1) and SNAT2 (SLC38A2) at different stages (D-17, D1 and D17) in porcine mammary glands

We estimated protein expression of three AA transporters to confirm if protein expression was consistent with mRNA expression (Fig. 5). Protein expression of ASCT1 was greater on both days postpartum compared with D-17, and protein expression of EAAT3 was greatest at D17 of lactation compared to D-17 and D1 $(P<0.05)$. Protein expression of SNAT2 increased from D-17 to D1 and continued to increase to D17 $(P<0.05)$.

\section{The adaptive regulation of AA transporters in PMEC}

In order to determine response of PMECs to changes in AA concentrations, we added different concentrations of AAs into cell medium and estimated AA transporter gene expressions using Real-time PCR. We also used EBSS as an AA-deficient cell-culturing medium and estimated AA transporter gene expressions after addition of different concentrations of AA complexes.

Gene expressions for SLC38A and SLC1A4 were detected in those cells treated with the neutral AA complex ( $L$-Ala, $L$-Ser and $L$-Cys), gene expression for SCL1A1 was detected in those cells treated with the acidic AA complex ( $L$-Asp and $L$-Glu), and gene expression for SLC6A14 was detected in those cells treated with the neutral + basic AA complex ( $L$-Ala, $L$-Ser, $L$-Cys and $L$-Lys) (Fig. 6).

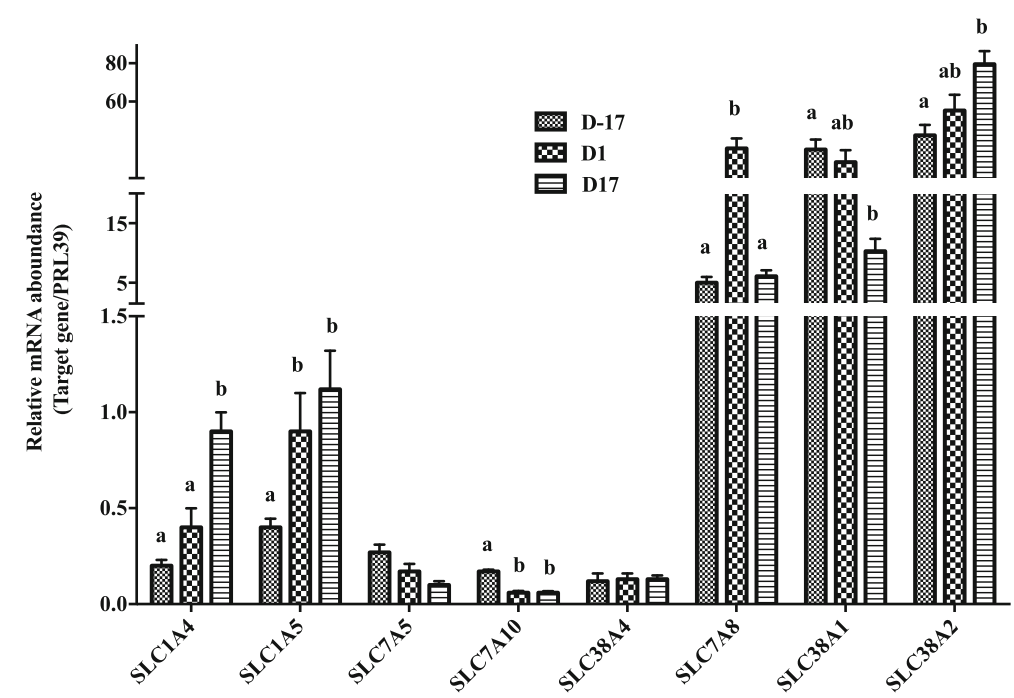

Fig. 3 The mRNA abundance of neutral AA transporters at different stages in porcine mammary gland. Gene expression of neutral AA transporters in sow mammary gland tissues at D-17, D1 and D17 of lactation. All data are shown as means \pm SEM. In the histogram of the same gene, values with different lower case letter superscripts differ $(P<0.05)$ 


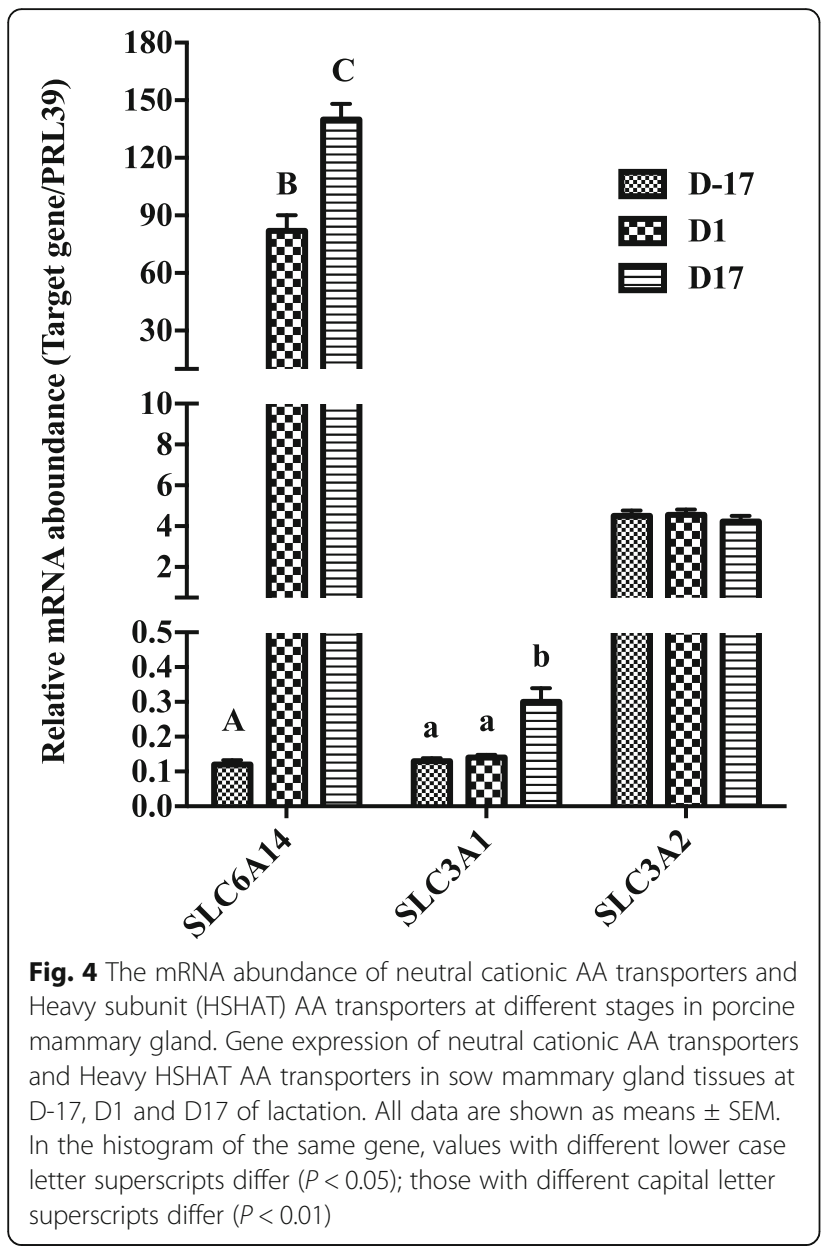

Gene expression of SLC1A4 was minimally affected when the amount of neutral AA complex was increased from $1 \times$ to $25 \times$, but the expression of SLC38A2 decreased when the AA complex concentration was increased to $5 \times$ compared with the control $(P<0.05)$. The expressions of both SLC38A2 and SLC1A4 were increased when AAs were eliminated from cell culturing medium, and SLC38A2 gene expression decreased when AA complex was re-added into EBSS $(P<0.05)$. However, there was little change in SLC1A4 expression when AA complexes were re-added into EBSS.

The gene expression of SCL1A1 in PMECs decreased significantly in the DMEM:F12 cell medium which was supplemented with $5 \times$ and $25 \times$ acidic AA complex $(P<$ $0.05)$, but there was little effect when the basal medium was changed to EBSS, and even when acidic AA complex was re-added into EBSS medium. We observed the same trend when we treated the PMECs using neutral + basic AA complexes. The expression of SLC6A14 was lower in the groups with $5 \times$ and $25 \times$ AA complex addition $(P<$ $0.05)$, but there was little difference between EBSS group and EBSS + AA complex group.

\section{Discussion}

It is well known that milk proteins are critical component of milk quality for mammals due to their important roles in newborn animal development and health [18]. Although lactation is a continuous process of milk secretion, there are two different phases of lactation: colostral phase (the colostrum contains large amounts of immunoglobulins and other immune defense proteins), and the mature secretion phases with much greater milk production supporting the rapid growth of the newborn [19]. In the present study, we analyzed milk components in colostrum (D1) and milk at D17 of lactation and the results showed that protein concentration in colostrum is significantly higher compared with milk at D17 postpartum, which are consistent with previous studies [20]. Because of the increased milk yield but decreased protein concentration on D17 of lactation from first day of lactation to the peak day, the changes of total milk protein synthesis were not clear. Therefore, we further estimated mRNA expression of genes coding for primary milk proteins in mammary tissue ( $\alpha$ s1-casein, $\alpha$ s2-casein, $\beta$-casein and $\mathrm{k}$-casein) to determine the regulation of milk protein synthesis at different physiological stages, both pre- and postpartum. Results demonstrated that mRNA expression of those genes coding for milk protein increased markedly from late pregnancy to peak milk production, implying more milk protein synthesis at peak lactation.

The porcine mammary gland has a large demand for free AAs to meet its high rate of milk production during lactation since more than $90 \%$ of milk protein is synthesized de novo in mammary tissue from the free AAs taken up from circulation [21]. Therefore, AAs provided to mammary glands are essential precursors for milk protein synthesis and their availability is a key limiting factor for milk protein production $[22,23]$. We determined the concentrations of free AAs in sow plasma, both pre- and postpartum, and the results showed that most AAs, including threonine, serine, alanine, valine, cysteine, methionine, isoisoleucine, tyrosine, phenylalanine, lysine, etc., increased significantly when the sow transitioned from pregnancy to lactation at D1. However, this rise in plasma AAs from late pregnancy to D1 postpartum was generally not maintained to D17 of lactation (day of peak lactation) despite estimates of milk protein synthesis being greatest at D17. It is a common phenomenon that sows, especially those with more than 12 piglets/litter, lose significant body weight during lactation because body tissues are catabolized to provide substrates for extensive milk synthesis in mammary glands [24]. Previously, several studies reported that AAs were released from muscle tissues through protein degradation and the degradation rate increased with the advance of lactation [25-27]. In our study, the increases in AA concentration at D1 of lactation might be attributed to protein degradation of sow body tissue to meet the requirement of milk 

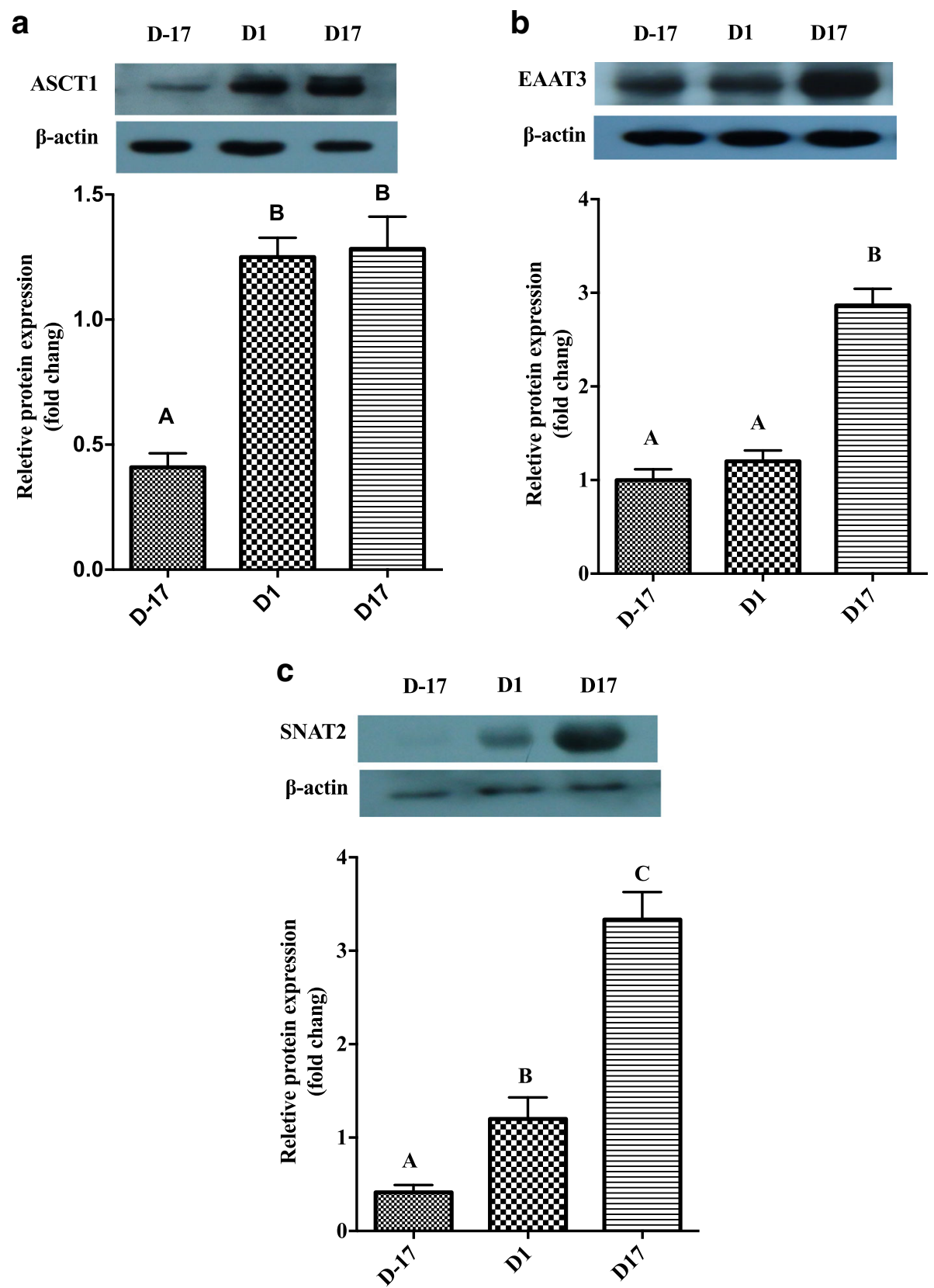

Fig. 5 Protein abundance of ASCT1, EAAT3 and SNAT2 at different stages in porcine mammary gland. Protein expression of AA transporters, including ASCT1 (a), EAAT3 (b) and SNAT2 (c) in sow mammary gland tissues at D-17, D1 and D17 of lactation. All data are shown as means \pm SEM. In the histogram of the same gene, values with different lower case letter superscripts differ $(P<0.05)$; those with different capital letter superscripts differ $(P<0.01)$

protein synthesis and lower concentration of AAs at D17 of lactation might be a consequence of higher milk protein synthesis with more AAs uptake from sow plasma AA at peak lactation.

Milk protein synthesis is not only determined by sow plasma AA availability, but is also controlled by transporter efficiency of AAs in the mammary glands [28, 29]. Guan et al. reported that mammary net uptake of some individual AAs (e.g., lysine) is a crucial rate-limiting step for the synthesis of milk protein in vivo [30] and Shennan et al. reported that the uptake of AAs from blood into the mammary glands was enhanced to sustain the synthesis of milk proteins during lactation [31]. In some species, such as cattle and mice, genes involved in transport processes also have been reported to be upregulated with stimulation of lactation [7]. AA uptake by the mammary gland is 


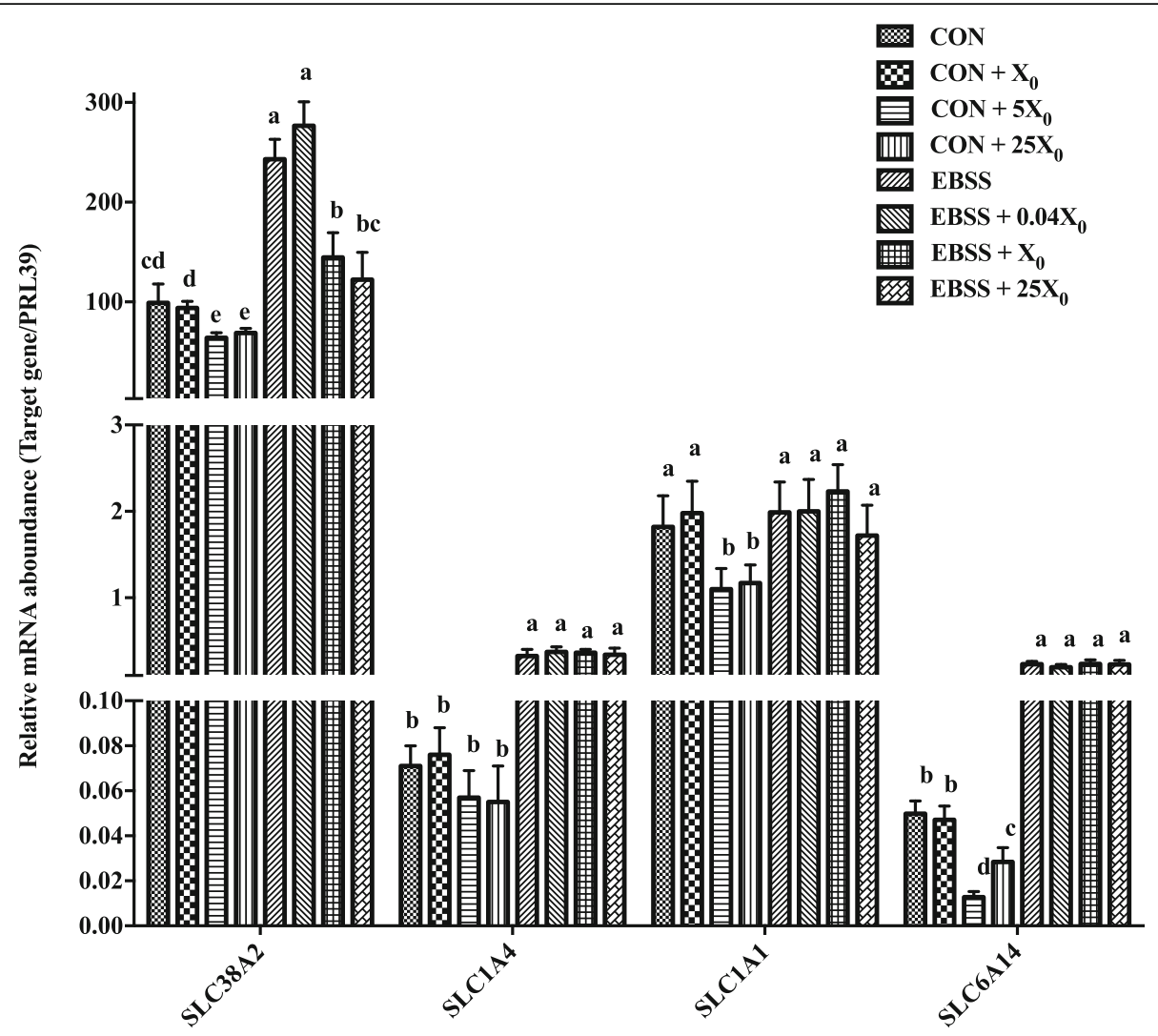

Fig. 6 The gene expression of SLC38A2, SLC1A4, SLC1A1, SLC6A14 in PMEC cells cultured with different concentration of AAs. Cells were assigned to 4 concentrations of AA complex in each of 2 mediums for each of 3 classes of AA complexes (Neutral AAs complex: L-Ala + L-Ser + LCys; Acidic AA complex: L-Asp + L-Glu; Neutral + basic AAs complex: L-Ala + L-Ser + L-Cys + L-Lys). Gene expression of SLC38A2 and SLC1A4 were detected in those cells treated with neutral AA complexes, SLC1A1 were detected in those cells treated with acidic AA complex, and SLC6A14 were detected in those cells treated with Neutral + basic AAs complex. All data are shown as means \pm SEM. In the histogram of the same gene, values with different lower case letter superscripts differ $(P<0.05)$

performed by different transporters located on the plasma membrane of the mammary epithelial cells. Generally, these systems can be subdivided into neutral, cationic, anionic, and others [32], some of which transport multiple AAs into and out of the cells as well [33]. We estimated the gene expressions of up to 8 neutral AA transporters, including SLC1A4, SLC1A5, SLC7A5, SLC7A10, SLC38A4, SLC7A8, SLC38A1 and SLC38A2 at the three different physiological stages, and we found that expressions of SLC1A4, SLC1A5 and SLC38A2 were relatively greater compared with other transporters, implying their dominant roles in AA transport during milk protein synthesis process. A number of studies reported that the SLC $38 A 2$ gene plays an important role in AA transport in mammary glands. For example, Tovar et al. reported that the expression of SLC38A2 increased significantly from late pregnancy to the start of lactation and then continue to the peak of lactation [34]. In our study, the gene of SLC38A2 increased significantly with the advance of lactation with maximal expression at D17 of lactation, suggesting that the efficiency of AA transport was enhanced to meet the demands of milk protein synthesis. Additionally, we also found the expressions of SLC1A4 and SLC1A5, the other two important neutral AA transporters, were increased significantly with the advance of lactation, which was consistent with the expression of SLC38A2. The gene expressions of both $S L C 1 A 1$ (anionic AA transporter) and SLC7A6 (cationic AA transporter) also significantly increased with the advance of lactation, which result was consistent with neutral AA transporters. Our present results suggest that increased milk protein synthesis and net AA uptake across the mammary gland with the advance of lactation from late pregnancy to peak lactation might be attributed to the enhanced expression of AA transporters.

It has been reported that AA transporters are regulated by several hormones, including insulin, glucagon, glucocorticoids growth hormone, and thyroid hormone etc. [35]. However, the role of a second type of AA transport regulation termed "adaptive regulation" is still unclear. In this process, the activity of AA transporters increases when cells are exposed to conditions of AA shortage or starvation (adaptive depression), while decreases when cells are 
exposed to conditions of abundant substrate AA (adaptive repression), as reported by Gazzol et al. [36]. It has been previously reported that mRNA abundance of AA transporters could be modulated by dietary protein intake and mammary AA uptake increased linearly with increasing dietary protein, suggesting a coordinated regulation between AA transporters and concentration of AAs to meet the demands for milk yield [37, 38]. In our study, although the changes in expression of each AA transporter with increased supplemental AA concentration differed, gene expressions of SLC38A, SCL1A1 and SLC6A14 declined significantly when we added up to $25 \times$ supplemental AA complex into PMEC mediums. This implies that sufficient duration and higher concentration of supplemental AAs would inhibit the expression of corresponding AA transporters to adaptively limit the uptake of AAs into PMECs. The gene expression of SLC38A4 increased significantly $4 \mathrm{~h}$ after AA elimination from the cell medium, then decreased to the level close to control group when substrate AAs were introduced back into the medium. It appears that adaptive regulation links transport activity and availability of AAs in the cell environment by affecting the expression of AA transporters in PMECs. It is noteworthy that the expressions of SLC1A4 and SLC6A14 increased rapidly under the condition with AA deficiency to ensure adequate uptake of AAs into PMECs, and the transporters continued to maintain increased expression even after reintroducing substrate AA into the cell medium. We speculate that these two transporters are less sensitive to AA concentration fluctuations and their expression in PMECs appears to require longer times to adjust to variations in AA concentrations, which possible mechanisms will be investigated in future studies. Furthermore, we also found that the gene expression of SCL1A1 showed higher stability evidenced by relatively less change in the AA supplemented groups and also no change in the AA starvation and shortage groups, implying different regulatory abilities of different transporters in PMECs.

\section{Conclusions}

In summary, AA transportation was positively regulated in sow mammary glands with the advance of physiological stage from late pregnancy to peak of lactation. Additionally, AA transporters in PMEC showed adaptive regulation with changes in AA concentrations of PMECs mediums. This novel finding is the first to report the expression and regulation mechanism of AA transporters at different physiological stages in the sow, providing basic information for the mechanism of milk protein synthesis in pigs and the potential to improve milk quality for swine industry.

\section{Abbreviations}

AA: Amino acid; ASCT1: Alanine/serine/cysteine/threonine transporter 1; EAAT3: Excitatory AA transporter 3; EBSS: Earle's balanced salt solution;
PMEC: Porcine mammary epithelial cell; SNAT2: Sodium-coupled neutral AA transporter 1

\section{Acknowledgements}

The authors thank the National Natural Science Foundation of China (No. 31402082) for supporting this study.

\section{Funding}

This work was financially supported by the National Natural Science Foundation of China (No. 31402082).

Availability of data and materials

The datasets analyzed in the current study are available from the corresponding author on reasonable request.

\section{Authors' contributions}

FC, WG, and SZ conceived and designed the experiment. FC and QZ, SZ, LC, $J C$ performed the trial and collected the experiments data. FC performed the statistical analysis. FC and SWK wrote the first draft of the manuscript. All authors critically reviewed the manuscript for intellectual content and gave final approval for the version to be published.

\section{Ethics approval}

The experiment was carried out according to Chinese guidelines for animal welfare and the National Institutes of Health guide for the care and use of Laboratory animals. All procedures related to animal feeding and surgeries were approved by the South China Agricultural University Animal Care and Use Committee.

\section{Consent for publication}

All authors read and approved the final manuscript.

\section{Competing interests}

The authors declare that they have no competing interests.

\section{Author details}

'Department of Animal Science, South China Agricultural University, Guangzhou 510642, China. ${ }^{2}$ National Engineering Research Center for Breeding Swine Industry, Guangzhou 510642, China. ${ }^{3}$ Department of Animal Science, North Carolina State University, Raleigh, NC 27695, USA.

Received: 16 July 2017 Accepted: 12 March 2018

Published online: 08 April 2018

\section{References}

1. Neville MC, Morton J, Umemura S. Lactogenesis. The transition from pregnancy to lactation. Pediatr Clin North Am. 2001;48:35-52.

2. Kim SW, Hurley WL, Han IK, Easter RA. Changes in tissue composition associated with mammary gland growth during lactation in the sow. J Anim Sci. 1999;77: 2510-6.

3. Kim SW, Easter RA, Hurley WL. Regression of non-suckled mammary glands during lactation in sows as influenced by the stage of lactation, dietary nutrients, and litter size. J Anim Sci. 2001;79:2659-68.

4. Ji F, Hurley WL, Kim SW. Characterization of mammary gland development in pregnant gilts. J Anim Sci. 2006;84:579-87.

5. Peaker $M$. The mammary gland in mammalian evolution: a brief commentary on some of the concepts. J Mammary Gland Biol Neoplasia. 2002;7:347-53.

6. Rudolph MC, McManaman JL, Hunter L, Phang T, Neville MC. Functional development of the mammary gland: use of expression profiling and trajectory clustering to reveal changes in gene expression during pregnancy, lactation, and involution. J Mammary Gland Biol Neoplasia. 2003;8:287-307.

7. Finucane KA, McFadden TB, Bond JP, Kennelly JJ, Zhao FQ. Onset of lactation in the bovine mammary gland: gene expression profiling indicates a strong inhibition of gene expression in cell proliferation. Functional \& integrative genomics. 2008:8:251-64.

8. Shu DP, Chen BL, Hong J, Liu PP, Hou DX, Huang X, et al. Global transcriptional profiling in porcine mammary glands from late pregnancy to peak lactation. OMICS. 2012;16:123-37 
9. LV Y, Guan W, Qiao H, Wang C, Chen F, Zhang Y, et al. Veterinary medicine and Omics (Veterinomics): metabolic transition of milk triacylglycerol synthesis in sows from late pregnancy to lactation. OMICS. 2015;19:602-16.

10. Chen F, Chen B, Guan W, Chen J, Lv Y, Qiao H, et al. Metabolic transition of milk lactose synthesis and up-regulation by AKT1 in sows from late pregnancy to lactation. Cell Biochem Biophys. 2017;75:131-8.

11. Ford JA, Kim SW, Rodriguez-Zas S, Hurley WL. Quantification of mammary gland tissue size and composition changes during the post-weaning period in sows. J Anim Sci. 2003;81:2583-9.

12. Shennan DB, Boyd CA. The functional and molecular entities underlying AA and peptide transport by the mammary gland under different physiological and pathological conditions. J Mammary Gland Biol Neoplasia. 2014;19:19-33.

13. Huber $\mathrm{L}$, de Lange CFM, Ernst CW, Krogh U, Trottier NL. Impact of improving dietary amino acid balance for lactating sows on efficiency of dietary amino acid utilization and transcript abundance of genes encoding lysine transporters in mammary tissue. J Anim Sci. 2016;94:4654-65.

14. Rezaei R, Wu ZL, Hou YQ, Bazer FW, Wu GY. Amino acids and mammary gland development: nutritional implications for milk production and neonatal growth. J Anim Sci Biotechno. 2016;7:1-22.

15. Kim SW, Hurley WL, Hant IK, Easter RA. Growth of nursing pigs related to the characteristics of nursed mammary glands. J Anim Sci. 2000;78:1313-8.

16. Manjarin R, Zamora V, Wu G, Steibel JP, Kirkwood RN, Taylor NP, et al. Effect of supply in reduced crude protein diets on performance, efficiency of mammary uptake, and transporter gene expression in lactating sows. J Anim Sci. 2012;90:3088-100.

17. Liu W, Saint DA. A new quantitative method of real time reverse transcription polymerase chain reaction assay based on simulation of polymerase chain reaction kinetics. Anal Biochem. 2002;302:52-9.

18. Alston-Mills T. The relationship between composition of sow's milk and casein pellet solvation. Livest Prod Sci. 1997:50:166

19. Anderson SM, Rudolph MC, McManaman JL, Neville MC. Key stages in mammary gland development. Secretory activation in the mammary gland: it's not just about milk protein synthesis. Breast Cancer Res. 2007;9:204.

20. Wu WZ, Wang XQ, Wu GY, Kim SW, Chen F, Wang JJ. Differential composition of proteomes in sow colostrum and milk from anterior and posterior mammary glands. J Anim Sci. 2010;88:2657-64.

21. Backwell FR, Bequette BJ, Wilson D, Metcalf JA, Franklin MF, Beever DE, et al. Evidence for the utilization of peptides for milk protein synthesis in the lactating dairy goat in vivo. Am J Phys. 1996;271:R955-60.

22. Bequette BJ, Backwell FR, Crompton LA. Current concepts of AA and protein metabolism in the mammary gland of the lactating ruminant. J Dairy Sci. 1998;81:2540-59.

23. Reynolds CK, Harmon DL, Cecava MJ. Absorption and delivery of nutrients for milk protein synthesis by portal-drained viscera. J Dairy Sci. 1994;77: 2787-808.

24. Hultén F, Neil M, Einarsson S, Håkansson J. Energy metabolism during late gestation and lactation in multiparous sows in relation to backfat thickness and the interval from weaning to first estrus. Acta Vet Scand. 1993;34:9-20.

25. Tokach MD, Pettigrew JE, Dial GD, Wheaton JE, Crooker BA, Johnston LJ. Characterization of luteinizing hormone secretion in the primiparous sow: relationship to blood metabolites and return-to-estrus interval. J Anim Sci. 1992;70:2195-201.

26. Trottier, N. L. Protein metabolism in the lactating sow. 1995. PhD Thesis, University of Illinois.

27. Trottier NL, Easter RA. Dietary and plasma branched-chain AAs in relation to tryptophan: effect on voluntary feed intake and lactation metabolism in the primiparous sow. J Anim Sci. 1995;73:1086-92.

28. Hyde R, Taylor PM, Hundal HS. AA transporters: roles in AA sensing and signalling in animal cells. Biochem J. 2003;373:1-18.

29. Manjarin R, Bequette BJ, Wu GY, Trottier NL. Linking our understanding of mammary gland metabolism to AA nutrition. AAs. 2014;46:2447-62.

30. Guan X, Bequette BJ, Calder G, Ku PK, Ames KN, Trottier NL. AA availability affects $A A$ flux and protein metabolism in the porcine mammary gland. J Nutr. 2002;132:1224-34.

31. Shennan DB, Peaker M. Transport of milk constituents by the mammary gland. Physiol Rev. 2000;80:925-51.

32. Kanai Y, Hediger MA. The glutamate and neutral AA transporter family: physiological and pharmacological implications. Eur J Pharmacol. 2003;479:237-47.

33. Baumrucker CR. AA Transport systems in bovine mammary tissue. J Dairy Sci. 1985;68:2436-51.
34. Tovar AR, Avila E, DeSantiago S, Torres N. Characterization of methylaminoisobutyric acid transport by system a in rat mammary gland. Metabolism. 2000;49:873-9.

35. Friedberg SH, Oka T, Topper YJ. Development of insulin-sensitivity by mouse mammary gland in vitro. Proc Natl Acad Sci U S A. 1970;67:1493-500.

36. Gazzola GC, Franchi R, Saibene V, Ronchi P, Guidotti GG. Regulation of AA transport in chick embryo heart cells. I Adaptive system of mediation for neutral AAs Biochim Biophys Acta. 1972;266:407-21.

37. Laspiur JP, Burton JL, Weber PS, Moore J, Kirkwood RN, Trottier NL. Dietary protein intake and stage of lactation differentially modulate AA transporter mRNA abundance in porcine mammary tissue. J Nutr. 2009;139:1677-84.

38. Guan X, Pettigrew JE, Ku PK, Ames NK, Bequette BJ, Trottier NL. Dietary protein concentration affects plasma arteriovenous difference of AAs across the porcine. J Anim Sci. 2004;82:2953-63.

\section{Submit your next manuscript to BioMed Central and we will help you at every step:}

- We accept pre-submission inquiries

- Our selector tool helps you to find the most relevant journal

- We provide round the clock customer support

- Convenient online submission

- Thorough peer review

- Inclusion in PubMed and all major indexing services

- Maximum visibility for your research

Submit your manuscript at www.biomedcentral.com/submit

) Biomed Central 